\title{
13 Between State Mission and Everyday Life: Private Photographs of East Germans in Mozambique in the 1980s
}

As the Second World War came to an end, African colonies underwent tremendous political, social, and economic changes. The colonial powers Great Britain and France saw their economic base severely weakened after the Second World War, as newly founded liberation movements in those colonies began to revolt against their colonial rulers. As a result, most of the formerly colonized African countries achieved independence during the 1960s. Each state, however, faced similar problems in its attempt to overcome colonial legacies and to implement well-suited political systems. While few African countries consciously chose a capitalist path, many African governments at least theoretically pursued one form or another of socialism-derived from the assumption that capitalism was an extension of colonialism and imperialism. ${ }^{1}$ Socialism, therefore, was seen as a way to achieve liberation and future development.

Beginning with the armed struggle in 1964, it took the liberation movement Frente de Libertação de Moçambique (FRELIMO) until 1975 to achieve political independence in Mozambique. While British and French colonies followed a classic "neocolonial solution," Portugal remained uncompromising and refused to surrender its colonies. ${ }^{2}$ Following the Carnation Revolution in Portugal in April 1974, and the uprising in the other Portuguese colonies Angola and Guinea-Bissau, the colonial power was now unwilling and felt increasingly unable to retain its grip on power; ultimately, this condition, paired with FRELIMO's struggle for independence, resulted in the sovereignty of Mozambique on June 25, 1975. Though Portugal's presence in Mozambique was limited to the coastlines and specific trade routes in the hinterland for many centuries, the colonized had suffered greatly under the Portuguese, including from the exploitation of its people and resources to other foreign interests; forced labor and slavery, underdevelopment in the agricultural and economic sectors, illiteracy, malnutri-

1 Allen F. Isaacman and Barbara Isaacman, Mozambique: From Colonialism to Revolution (Boulder: Westview Press, 1985), 3; Bruce R. Bartlett, “Capitalism in Africa: A Survey,” The Journal of Developing Areas 24 (1990).

2 John S. Saul, A Difficult Road: The Transition to Socialism in Mozambique (New York: Monthly Review Press, 1985), 9.

Ә OpenAccess. () 2021 Katrin Bahr, published by De Gruyter. (cc)BY This work is licensed under the Creative Commons Attribution 4.0 International License. https://doi.org/10.1515/9783110623543-013 
tion, tribalism, and racism had turned Mozambique into one of the poorest African countries. ${ }^{3}$

The experience of Portuguese colonialism, marked by economic exploitation, and the foreseen threat of neighboring anti-communist countries, led FRELIMO to direct its political mission towards socialist countries and to establish a "Socialism with a Mozambican face." One of FRELIMO's allies was the German Democratic Republic (GDR)-which, due to the West German Hallstein Doctrine, itself struggled for state recognition since 1955. First contacts between the GDR's ruling Socialist Unity Party (SED) and FRELIMO were established in the 1960s when the East German government agreed to train Mozambican FRELIMO fighters in the GDR, financed by the Solidarity Committee of the GDR. ${ }^{5}$ Additionally, a handful of East German specialists ${ }^{6}$ were sent to Mozambique to teach in the camps of FRELIMO. ${ }^{7}$ The exodus of Portuguese settlers on the eve of Mozambique's political independence left the country devastated with neither trained personnel nor the infrastructure and technical equipment to reconstruct its economy. Based on the cordial relations established during FRELIMO's liberation struggle, the SED government intensified its collaboration with Mozambique. Those first socialist encounters led to the signing of the Treaty of Friendship (Freundschaftsvertrag) on February 24, 1979. ${ }^{8}$ Furthermore, they strengthened the relations between the two countries and paved the way for thousands of East German specialists and their families who would visit the country over the next ten years. ${ }^{9}$ In the GDR's official discourse, these specialists arrived under the prospect of international solidarity. As a concept, international solid-

3 Saul, A Difficult Road, 36-48; Isaacman and Isaacman, Mozambique, 3, 27-60.

4 Isaacman and Isaacman, Mozambique, 3; Saul, A Difficult Road, 9-31.

5 See Ilona Schleicher, "Berufsbildung und Wirtschaftsbeziehungen der DDR-Mosambik," in Engagiert für Afrika: Die DDR und Afrika II, ed. Ulrich van der Heyden, Ilona Schleicher, and Hans-Georg Schleicher (Münster: Lit, 1994), 179-180; Hans-Georg Schleicher, "The German Democratic Republic (GDR) in the Liberation Struggle of Southern Africa," in Southern African Liberation Struggles: Contemporaneous Documents, 1960-1994, ed. A. J. Temu and Joel das Neves Tembe (Dar es Salaam, Tanzania: Mkuki na Nyota Publishers, 2014), 507-598.

6 In the bureaucratic jargon of the GDR, the term specialist (Spezialist) referred to citizens working abroad.

7 Matthias Voß, "Um de nós - einer von uns! Gespräch mit Achim Kindler, der als Lehrer im Auftrag des Solidaritätskomitees der DDR als erster DDR-Bürger bei der FRELIMO arbeitete,” in Wir haben Spuren hinterlassen! Die DDR in Mosambik: Erlebnisse, Erfahrungen und Erkenntnisse aus drei Jahrzehnten, ed. Matthias Voß (Münster: Lit, 2005), 34-46.

8 Schleicher, "Berufsbildung und Wirtschaftsbeziehungen DDR-Mosambik," 179-195.

9 For more information on the negotiations of the contract labor accord between the GDR and Mozambique and the sending of Mozambican contract workers (Vertragsarbeiter) to the GDR see Franziska Rantzsch in this volume. 
arity was seen as the counter-project to the Western understanding of development aid, and was interpreted as a relationship among equals; "instead of continuity with the past, it emphasized rupture; instead of otherness, likeness; instead of differentiation, integration; and instead of continuing subjugation, political emancipation."10 Depending on the work assignments, East German specialists remained in Mozambique for a period of six months to three years, and were deployed across the country, with the majority living in the capital Maputo. ${ }^{11}$ Beyond their solidarity, GDR citizens brought their technical knowledgeoccupations ranged from railway engineers, mechanics, and bricklayers to teachers, doctors, and geologists. Equipped with their cameras, East Germans took snapshots both at their workplaces and in their domestic environments. Largely, though, the people who took these private photographs were amateurs in our current understanding of the word.

While scholars became increasingly interested in the foreign policy of the GDR in the early 1990s, most of the resulting research remained limited to the political and economic sphere. ${ }^{12}$ More recent studies have begun to look at the everyday life experiences of East Germans, focusing on the working and living conditions abroad and the collaborations with their respective counterparts. ${ }^{13}$

10 Toni Weis, "The Politics Machine: On the Concept of 'Solidarity' in East German Support for SWAPO," Journal of Southern African Studies 37 (2011).

11 They were divided into three groups: Reisekader (short-term deployment up to six months and business trips), Auslandskader (long-term deployment up to three years), and FDJ-Brigadisten (young people from the Free German Youth Brigades, the official youth organization of the GDR). Only the Auslandskader and sometimes also the FDJ brigade leaders were allowed to bring along their families (with restriction). See also Jens Niederhut, Die Reisekader: Auswahl und Disziplinierung einer privilegierten Minderheit in der DDR (Leipzig: Evangelische Verlagsanstalt, 2005) and Informationen über das Kollektiv der DDR-Bürger in der VRM, Botschaft der DDR in der VRM, Maputo 5.7.1989, Stiftung Archiv der Parteien und Massenorganisationen der DDR im Bundesarchiv, Berlin (henceforth: SAPMO-BArch), DY 30/14095.

12 Some pioneering works worth mentioning are Siegfried Baske and Gottfried Zieger, Die Dritte Welt und die beiden Staaten in Deutschland (Asperg: Edition Meyn, 1983); Gareth M. Winrow, The Foreign Policy of the GDR in Africa (Cambridge: Cambridge University Press, 1990); Ilona Schleicher and Hans-Georg Schleicher, Die DDR im südlichen Afrika: Solidarität und Kalter Krieg (Hamburg: Institut für Afrikakunde, 1997).

13 Iris Christina Obernhummer, "Experten der 'wissenschaftlich-technischen Zusammenarbeit' der DDR in Afrika: Alltag und Lebensweisen zwischen DDR-Richtlinien und angespannter Sicherheitslage in den 1970er und 1980er Jahren” (diploma thesis, University of Vienna, 2010); Hubertus Büschel, Hilfe zur Selbsthilfe: Deutsche Entwicklungsarbeit in Afrika 1960-1975 (Frankfurt am Main: Campus Verlag, 2014); Alexandra Piepiorka, "Exploring 'Socialist Solidarity' in Higher Education: East German Advisors in Post-Independence Mozambique (1975-1992),” in Education and Development in Colonial and Postcolonial Africa, Global Histories of Education: Policies, Para- 
Edited volumes that include interviews with former specialists about their experiences in Mozambique established another narrative of the GDR's participation in Africa. ${ }^{14}$ Researchers became increasingly interested in the visual representation of everyday life within the GDR, but have not yet looked across the borders of the nation state. While researchers have begun to discuss the representation of international solidarity in official state photographs, ${ }^{15}$ scholars have yet to make use of private photographs taken by East Germans documenting socialist encounters, solidarity, and the everyday life in African and other non-European countries.

In this chapter, I show that private photographs are documents of vital importance for the discussion of the GDR's participation in development activities abroad, and, more specifically for this work, in Mozambique. Firstly, private photographs give insights into the different lives of East Germans and their individual interactions and entanglements with Mozambicans. They combine a personal-political message of the state and the photographer's own endeavor to apply international solidarity in that moment and space. The everyday life (Alltagsleben $)^{16}$ that East Germans experienced abroad contrasted with their lives in the GDR. Importantly, the private pictures that East Germans took serve as a counter narrative to the existing photographs of the Allgemeiner Deutscher Nachrichtendienst (ADN)-the main state news agency that published its photographs in various newspapers and magazines. ${ }^{17}$ While most of the official photographs only portray the (overwhelmingly male) specialists at work, the private photographs, in contrast, portray a number of aspects of the everyday life abroad that were usually absent in the state-official portrayals. In this context, a more gendered

digms, and Entanglements, 1890s-1980s, ed. Damiano Matasci et al. (Cham: Palgrave Macmillan, 2020), 289-318; Alexandra Piepiorka and Eduardo F. Buanaissa, this volume.

14 Two edited volumes should be mentioned here: Matthias Voß, Wir haben Spuren hinterlassen! Die DDR in Mosambik: Erlebnisse, Erfahrungen und Erkenntnisse aus drei Jahrzehnten (Münster: Lit, 2005); Hans-Joachim Döring and Uta Rüchel, Freundschaftsbande und Beziehungskisten: Die Afrikapolitik der DDR und der BRD gegenüber Mosambik (Frankfurt am Main: Brandes und Apsel, 2005).

15 Büschel, Hilfe zur Selbsthilfe, 271-274; Gregory Witkowski, "Between Fighter and Beggars," in Comrades of Color: East Germany in the Cold War World, ed. Quinn Slobodian (New York: Berghahn Books, 2015), 73-94.

16 Alf Lüdtke, Alltagsgeschichte: Zur Rekonstruktion historischer Erfahrungen und Lebensweisen (Frankfurt: Campus, 2018 [1989]), 21.

17 Photographs addressing the development of African countries can be found in the daily newspapers Neues Deutschland (ND) and Junge Welt (JW), and the weekly magazine for international politics Horizont, Neue Berliner Illustrierte (NBI) and the illustrated magazine for women Für Dich. 
perspective becomes visible. Crucially, the pictures illuminate the various roles of women within the concept of international solidarity and their participation in the preservation of a Eurocentric idea at home. Women are portrayed organizing solidarity bazaars with other socialist countries and undertaking leisurely activities such as knitting Macramé (a knitting technique to create wall hangings, tablecloths, and other home furnishings). And finally, while those photographs are private snapshots, they also show how colonial structures were perpetuated by the concept of solidarity. The photographs highlight that the state ideology of anti-racism and anti-colonialism did not hold off the white male gaze but rather assumed a certain superiority towards their subjects of interest.

To substantiate my claims, I will first explore the meaning of photography as a medium that reflects on Alltagsleben. In this context, it is important to examine the various genres of photography that were used in the GDR in order to be able to embed private photographs in the broader discourse of GDR amateur photography and its representation of GDR culture. Secondly, I will discuss the representation of East German specialists and their Mozambican counterparts in official state photographs and how those photographs were connected to the understanding of international solidarity and the GDR's state mission. Having set the foundation for the use of photographs to discuss the GDR's involvement in Africa, I will then analyze the meaning of private photographs. During a research trip to Germany in 2016, I received over 2,000 photographs from my German interview partners who were on long-term deployment in Mozambique in the 1980s. Most of these photos came without caption and can therefore only be discussed on an image-based analysis. The photographs discussed in this chapter all appear with context provided by my interview partners-as such, a text-based analysis accompanies these photos. The historical contribution of the aforementioned interviews, however, has to be evaluated critically as they constitute constructions of memories that partly aim to justify one's own action. ${ }^{18}$

Moreover, I discuss photographs of two travel reports published by GDR specialists working in Mozambique during the 1980s. In my analysis, I differentiate between work and leisure time, and show the personal lens East Germans applied when taking photographs. Importantly, I will also include the types of representation of East German women in those pictures. In closing, I trace colonial continuities in both the official and private photographs I have analyzed.

18 Cf. Piepiorka and Buanaissa, this volume. 


\section{Photographs as a Medium to Document Alltagsleben}

The use of photography as a medium for documenting everyday life creates a relationship between those people who take and those who view photographs. Pictures taken with a camera are socially distinct objects that exist and interact in a certain time and space, moving between the past and the present, and therefore reflect on the social and cultural experiences of the photographers. They tell stories that are carried on visually and orally. Photographs are social objects that have a certain effect in conveying the stories and experiences of the photographers and incorporate real-life experiences, biographical narratives, and agen$\mathrm{cy}^{19}$

In evaluating East German photographs, researchers have mainly focused on the artistic or professional photography produced of the SED government. ${ }^{20}$ Studies on amateur photographs as part of the state's project mostly refer to the pictures of Betriebsfotogruppen, photographic circles which operated in many state-owned companies abbreviated VEBs (Volkseigene Betriebe). ${ }^{21}$ In the 1950s it was the German Cultural Association (Deutscher Kulturbund) and the Free German Trade Union Confederation (Freier Deutscher Gewerkschaftsbund, aka FDGB), which tried to establish amateur photography (Hobbyfotografie) as part of "photo work in the service of socialism,"-a classification that was consequently meant to also control its people. ${ }^{22}$ In her book Greif zur Kamera, Kumpel!, cultural historian Regine Schiermeyer points out that in the eyes of the GDR

19 Elizabeth Edwards, "Photography and the Material Performance of the Past," History and Theory 48 (2009); Elizabeth Edwards and Janice Hart, "Introduction: Photographs as Objects," in Photographs Objects Histories: On the Materiality of Images, ed. Elizabeth Edwards and Janice Hart (London: Routledge, 2010); Susan Sontag, Regarding the Pain of Others (New York: Picador, 2003), 85; Tina M. Campt, Image Matter: Archive, Photography, and the African Diaspora in Europe (Durham/London: Duke University Press, 2012), 6-7.

20 One of the most recent publications is Candice Hamelin's dissertation "Behind Immaterial and Material Divides: East German Photography 1949-1989” (PhD diss., University of Michigan, 2016).

21 Regine Schiermeyer, Greif Zur Kamera, Kumpel! Die Geschichte der Betriebsfotogruppen in der DDR (Berlin: Ch. Links, 2015), 165-166.

22 Karin Hartewig, "Einleitung," in Die DDR im Bild: Zum Gebrauch der Fotografie im anderen deutschen Staat, ed. Karin Hartewig and Alf Lüdtke (Göttingen: Wallstein, 2004), 10. For a short overview about the Kulturbund see also Kurt Ludwig, "Zwischen Anspruch und Anpassung: Der Kulturbund im kulturellen Alltag der DDR,” in Die DDR zwischen Mauerbau und Mauerfall, ed. Heiner Timmermann (Münster: Lit, 2003), 126-138. 
state, amateur photography was an "organized hobby photography with an artistic claim." ${ }^{23}$ According to cultural historian Karin Hartewig, the state differentiated between "serious amateur photographers" (ernsthafte Amateure) and "unreflective amateur photographers” (gedankenlose Knipser), who took pictures for their own private use. ${ }^{24}$ The state, however, was more interested in the "serious amateur photographers" who took pictures for their Brigadetagebücher, the brigade journals that documented the work of the brigade collective. ${ }^{25}$ In contrast to official GDR photographers, the so-called "unreflective amateur photographers" were those who took photographs without a primarily socialist intention, and whose pictures were therefore considered meaningless products.

Researchers have maintained the division between professional and amateur photographs in so far that the former are embedded in the narrative of presumed socialist success and achievement. ${ }^{26}$ But it was the "unreflective amateur photographers" who provided their own projections, with niches and forms of expression becoming increasingly important. Art historian Catherine Zuromski defines these private photographs as snapshots that do not belong to a clearly defined genre. A "subjective purity" differentiates them from other photographic genres and challenges the notion of a defined style or convention of any kind based on the plentiful number of photographs and the paradoxes they present. ${ }^{27}$ In the case of the GDR, those pictures are individual, non-normative, and unexpected, therefore, in complete contrast to the regime of control and standardization that the East German regime implemented. What makes them so interesting, moreover, is that they are not professionally shot rather sometimes blurred or improperly exposed. Most important is the setting in which they are "viewed, touched, framed, exchanged, discussed, remembered, collected, and, on certain occasions, defaced."28 By embedding them into social conventions and cultural patterns, the photographs document special events within the sphere of the individual, the family, or immediate relatives and friends. They follow a chronology

23 Schiermeyer, Greif zur Kamera, Kumpel!, 12.

24 Hartewig, "Einleitung," 10.

25 See Gerhard Henniger, Zur gesellschaftlichen Wirksamkeit der Amateurfotografie in der DDR: Hinweise und Erfahrungen (Berlin: Dt. Kulturbund, 1965), 5-6. Brigadetagebücher were also kept abroad by the friendship brigades of the FDJ working in African countries like Mali, Guinea, Zanzibar, and Angola. On the Brigadetagebücher of various friendship brigades working in Angola see Paul Sprute in this volume.

26 Hartewig, "Einleitung," 11.

27 Catherine Zuromski, Snapshot Photography: The Lives of Images (Cambridge: The MIT Press, 2013), 8-9.

28 Zuromski, Snapshot Photography, 48. 
that reveals the everyday life of the photographers and the people being photographed.

\section{The Power of Images: Official State Photographs}

In a 1988 interview conducted with the Horizont - a weekly magazine reporting on international politics and economy-Kurt Seibt, chairman of the Central Revision Commission of the SED and Chairman of the Solidarity Committee of the GDR, spoke about the importance of promoting solidarity with other peoples and nations. While the GDR already had a history of almost three decades of solidarity aid in African, Latin American, and Asian countries, Seibt stressed the continuing effort to anchor the idea of solidarity with those countries in the consciousness of the East German population. Although a continuous increase in public donations was fundamental to the solidarity campaigns, it was also considered important "that the unifying idea of solidarity is supported in all collectives and in all families. This is even more effective [...] when we bring our citizens closer to the struggle, the suffering and hopes of the people of Asia, Africa, and Latin America." ${ }^{29}$ In this sense, photographs became an important part in showing the struggle in those countries firsthand. ${ }^{30}$

Besides depicting poverty and destruction in the aforementioned regions,which Susan Sontag describes as a "gazing on other people's reality with curiosity but also detachment"-these photographs also highlighted East German accomplishments. ${ }^{31}$ Showing one's own accomplishment was not a new concept and had already accompanied the intrusion of Europeans before the advent of colonialism. ${ }^{32}$ In this context, photography was used as a tool "through which

29 “[...] dass die völkerverbindende Idee der Solidarität in alle Kollektive, in alle Familien getragen wird. Das wird um so wirkungsvoller gelingen, [...] wenn wir unseren Bürgern den Kampf, das Leid und die Hoffnungen der Menschen Asiens, Afrikas und Lateinamerikas nahebringen.” Ein festes Band von Managua bis Hanoi: interview with Kurt Seibt, chairman of the Central Revision Commission of the Socialist Unity Party of Germany (SED) and chairman of the Solidarity Committee of the GDR, Horizont, 8/1988, 3-4. Author's own translation.

30 For a discussion on the representation of development work in East German newsreels, see also George Bodie in this volume.

31 Susan Sontag, On Photography (New York: Picador, 1973), 55.

32 See, for instance, Willeke Sandler's article "Deutsche Heimat in Afrika: Colonial Revisionism and the Construction of Germanness through Photography," Journal of Women's History 25 (2013), doi:10.1353/jowh.2013.0000; Henrik Stahr, Fotojournalismus zwischen Exotismus und Rassismus: Darstellungen von Schwarzen und Indianern in Foto-Text-Artikeln deutscher Wochenillustrierter 1919-1939, (Hamburg: Kovač, 2004). 
Europeans sought to establish, stabilize and disseminate concepts about African pasts and imaginaries about African futures." 33 Photographs served as documentation of the work of missionaries in Africa, including their construction of missionary schools and hospitals. Photographs also served to legitimate and illustrate one's own missionary work abroad and were used to raise donations in the home country. ${ }^{34}$ As scholars Richard Vokes and Darren Newbury state, "the photograph's orientation towards the future emerges not only from the semiotics of their representations but also from the ways in which they are circulated and deployed." 35 It is therefore not a surprise that those concepts continued to exist with decolonization and postcolonial independence in the making following the Second World War. While the Cold War saw an arms race between the East and West, it also highlighted competing ideologies. Within this rivalry, both the United States and the Soviet Union used photography as part of their mission in Africa. The resulting images were meant to represent solidarity in building a future that each country had in mind for its African "recipient country". 36

The GDR engaged itself in shaping narratives. Solidarity in the GDR was supposed to be everyone's concern, and therefore had to be staged accordingly. The "staging of help" on television and in newspapers and magazines promoted, on the one hand, the willingness of the population to donate. On the other hand, it promoted political and ideological education. ${ }^{37}$ Portrayals of encounters involving socialist assistance and support were personalized by the faces of East German specialists and the friendship brigades (Freundschaftsbrigaden) of the Free German Youth, or FDJ (Freie Deutsche Jugend). As historian Hubertus Büschel ar-

33 Richard Vokes and Darren Newbury, "Editorial: Photography and African futures," Visual Studies, 33 (2018): 2. doi:10.1080/1472586X.2018.1424988. On the definition of images as objects see also Elizabeth Edwards, “Objects of Affect: Photography beyond the Image," Annual Review of Anthropology 41 (2012): 221-234, doi:10.1146/annurev-anthro-092611-145708.

34 Joachim Zeller, and Peter Weiss, Weisse Blicke, schwarze Körper: Afrikaner im Spiegel westlicher Alltagskultur (Erfurt: Sutton Verlag, 2010); T. Jack Thompson, Light on Darkness? Missionary Photography of Africa in the Nineteenth and Early Twentieth Centuries (Grand Rapids, Mich: Eerdmans Publ., 2012); Nina Berman and Klaus Mühlhahn and Patrice Nganang, eds., German Colonialism Revisited: African, Asian, and Oceanic Experiences (Ann Arbor: Michigan Press, 2018).

35 Vokes and Newbury, "Editorial: Photography and African futures," 2.

36 Vokes and Newbury, "Editorial: Photography and African futures," 4.

37 Witkowski, "Between Fighter and Beggars," 74-80; Quinn Slobodian, "Socialist Chromatism: Race, Racism, and the Racial Rainbow in East Germany," in Comrades of Color: East Germany in the Cold War World, ed. Quinn Slobodian (New York: Berghahn Books, 2015), 23-39. See also Bodie, this volume. 
gues, the photographs of the specialists' work abroad created a narrative of the "developed" GDR with a "still-in-development" Africa. ${ }^{38}$ According to historian Jürgen Osterhammel, the "civilizing mission” (Zivilisierungsmission) from colonial times carries on into the present day. ${ }^{39}$ During the Cold War, the civilizing mission transformed into a new developmental strategy of strategic support, the Hilfe zur Selbsthilfe or solidarity for self-help, in order to create a lasting order of ideologies from the supporting countries. ${ }^{40}$ Education and training was the focus of the GDR's development policies and the success of such solidarity projects was documented in the state's newspapers and magazines. Photographs depicting East Germans with their counterparts often showed East Germans explaining the handling of machinery and equipment to Africans, all while the latter appeared to be watching closely. Africans are thereby depicted as the ones who must pave the path to modernity, to catch up, and to make progress. ${ }^{41}$ This is the very same narrative Büschel describes for the West German specialists who appeared in scientific journals and newspapers. The photographs also connect to patterns used in the GDR's representation of work and its worker in the 1950s, in which we often see an experienced worker explaining something to his colleagues gathered around him. The speaker usually points with a distinctive hand gesture at the discussed object, such as a part of a machine. As art historian Agneta Maria Jilek further notes, these types of images were meant to establish an authentic atmosphere of a newly created world..$^{42}$

The theme of labor as a representation of establishing socialism and economic wealth was already incorporated in the state's art photography in the GDR in the 1950s. In doing so, the human being was seen as a major player in the construction of the socialist society and state. ${ }^{43}$ This image motif and the creation of the "New Man"-the development of a new socialist personality-were also being used for the development work in African countries. Within these representations, the East German worker was seen as a symbol for the successful

38 Hubertus Büschel, “In Afrika helfen: Akteure westdeutscher 'Entwicklungshilfe' und ostdeutscher 'Solidarität' 1955-1975,” in Dekolonisation: Prozesse und Verflechtungen 1945-1990, ed. Anja Kruke (Bonn: Dietz, 2009), 350.

39 Jürgen Osterhammel, "'The Great Work of Uplifting Mankind”: Zivilisierungsmission und Moderne," in Zivilisierungsmissionen: Imperiale Weltverbesserung seit dem 18. Jahrhundert, ed. Boris Barth and Jürgen Osterhammel (Konstanz: UVK, 2005), 422.

40 On the concept of "Hilfe zur Selbsthilfe" see Büschel, Hilfe zur Selbsthilfe, 85-115, 116-178. 41 Büschel, "In Afrika helfen,” 350; Büschel, Hilfe zur Selbsthilfe, 271-274.

42 Agneta Maria Jilek, “'Laßt uns pflügen, laßt uns bauen': Brigadebilder und Typenporträts in der DDR-Fotografie der frühen fünfziger Jahre," in Die DDR im Blick II: Ein zeithistorisches Lesebuch, ed. Anja Hertel, Franziska Kuschel, and Markus Böick (Berlin: Metropol, 2012), 151.

43 Jilek, “Laßt uns pflügen, laßt uns bauen'," 146. 
implementation of socialism, whose role now was to pass on the achievements to Africans. Mozambique's first president Samora Machel was eager to adapt this model since he himself believed that the country needed a fresh start by shaking off the shackles of colonialism and focusing on the future and the community to rebuild the country. The internationally deployed friendship brigades-who exported the GDR's socialist worker-were therefore a favored image motif in the representation of the personified development work; their work was not expressed as a contribution of the individual, but as a representation of the collective. ${ }^{44}$

Images of men at work served not only as a statement of productivity, but also as a representation of international solidarity. The East German specialists depicted in official photographs embodied this international solidarity and assistance themselves and served as a personification of development cooperation in a way that GDR citizens "back home," who donated money for the cause, could identify with. Personal stories and experiences were rarely reported in the East German press, and if so, only in smaller local newspapers. ${ }^{45}$ The photographs in newspapers and journals usually served as the visual background to report on the merits of the GDR in the development of cooperation. ${ }^{46}$ It was important to show the East German donors that GDR specialists utilized their money in a useful and monitored way. ${ }^{47}$

Authenticity also became an indicator for the definition and representation of the "other". As already mentioned, in addition to the motif of the work, which shows the achievements of the GDR, images of the local population also appeared in these newspapers and magazines. The camera captured everything that might be of interest to those at home who supported the solidarity efforts. Those photographs depict the local population in their everyday activities, sometimes staged with people standing in front of their huts, children presenting selfmade toys, or children sitting around a table playing with donated toys they received from the Solidarity Committee. For the most part, the photographs also meant to show the cultural differences, for instance children dancing in their traditional costumes. It was the GDR that defined how Mozambique and its citizens would be represented and, moreover, what needed to be seen. The cultural dif-

44 See Immanuel R. Harisch and Eric Burton, "Sozialistische Globalisierung: Tagebücher der DDR-Freundschaftsbrigaden in Afrika, Asien und Lateinamerika," forthcoming in Zeithistorische Forschungen / Studies in Contemporary History.

45 Interview with a former ADN journalist in Mozambique 1987-1990, conducted on June 15, 2016 in Berlin.

46 See Junge Generation, a theoretical magazine of the FDJ, 3-88, 50 and NBI 7/82, 29.

47 See Für Dich, 10/84, 12, 19. 
ferences as presented in those photographs continued to create a picture of colonizer and colonized. ${ }^{48}$

\section{The Power of Images: Everyday Life Abroad}

Most of the official state photographs were taken by professionals who were sent to Mozambique by the ADN to document the GDR's projects abroad. Their job assignments were precisely defined, with usually one place and one project to be visited during that time. In contrast, private photographs took on a completely new meaning, as they not only allowed amateur photographers to be their own narrators, but also illustrated how those amateur photographers positioned themselves and others in the context of the political, social, and cultural environment in Mozambique. This "other view" moved away from the state propaganda image towards the portrayal of the everyday life of the individual. In this context, the presented themes, the origin of the photograph, the time when the photograph was taken, and the historical background played decisive roles in narrating these photographs.

Based on the owners of the photographs I received and the subjects depicted in these photographs, one can assume that it was usually the East German men who had their cameras with them at work or when traveling through the country. The main reason for this was the number of East German men deployed abroad, which exceeded the number of women working. ${ }^{49}$ However, an interesting question that deserves further research is the question of the male and female gaze and if there was a difference in the pictures taken by women compared with those taken by men. Most of these private photographs were taken as souvenirs to document the workplace and surroundings in Mozambique, and later shared with friends, family or relatives in the GDR. Some of the photographers also showed their pictures in presentations at school or at work after they had re-

48 Homi Bhabha. "Framing Fanon, Foreword," in The Wretched of the Earth, ed. Frantz Fanon et al. (New York: Grove Press, 2004 [1961]), ix.

49 In 1989, 342 East Germans were deployed in Mozambique, 194 of them were men, 135 women, and 13 children. Looking at the positions occupied by East Germans, it becomes clear that the number of working women was below 100. For a specific example see Maputo with the largest group of specialists in the country: APO I (embassy and advisors/65), APO II (Council of Ministers Working Group/47), APO III (department of trade policy/30), APO IV (advisors and specialists/35), APO V (national education/28), APO VI (university/12), Informationen über das Kollektiv der DDR-Bürger in der VRM, Botschaft der DDR in der VRM, Maputo 5.7.1989, SAPMO-BArch, DY 30/14095. 
turned. For this purpose, the photos were usually developed as slides to facilitate projection. ${ }^{50}$ Although color films were expensive, most of the photos displayed appeared in color. Usually, the film rolls were brought home undeveloped during vacation in the GDR or were given to other East Germans who went home for vacation or whose time abroad had come to an end. This procedure bypassed the formal requirement of the state to have all correspondence (for security reasons) sent through the dispatch of the embassy, as well as random checks for material that the GDR state might find inappropriate and counterproductive for its display of solidarity. ${ }^{51}$

The photographs I analyze span over a period of ten years and show recurring similarities in themes that reflect everyday life of East Germans in Mozambique. Based on those similarities, photographs can be roughly divided into the following categories: family life, work and labor, leisure activities, work collective, nature, and representation of the local population. For this contribution, I focus on the themes of family life, work and labor, leisure activities, and representation of the local population. I argue that these photographs must be viewed in the context of the place and time of the deployment, the profession of the East Germans, and above all, the interest behind the motifs. Due to their work assignments, some East Germans traveled more frequently than others throughout the country, and thus had more opportunities to capture their varying impressions with the camera. As the internationally supported civil war in Mozambique spread in the mid-1980s, excursions into the countryside consequently diminished. These trips came to a complete halt with the vicious attack on nine GDR agriculture specialists on December 6, 1984, in which eight of them died. ${ }^{52}$ They had worked at one of the state farms in Lichinga and were ambushed while leaving their homes to drive to the nearby farm they worked at. After this event, the fear for the safety of the East Germans increased. As a result, the photographs that depicted travels of East Germans in the country decreased and photographs of the private sphere came more to the fore. What the photographs also show in that respect is how the safety mea-

50 All of the photographs I received from my interview partners came as slides.

51 Interview with former specialist B. about the mailing of film material back to the GDR, conducted on June 2, 2016 in Berlin.

52 Monika Smardz, "Bis zu jenem Tag im Dezember - Eine Farm mitten in der Savanne," in Wir haben Spuren hinterlassen! Die DDR in Mosambik: Erlebnisse, Erfahrungen und Erkenntnisse aus drei Jahrzehnten, ed. Matthias Voß (Münster: Lit, 2005), 270 - 277; Ulrich van der Heyden, "Es darf nichts passieren! Entwicklungspolitisches Engagement der DDR in Mosambik zwischen Solidarität und Risiko," in Wir haben Spuren hinterlassen! Die DDR in Mosambik: Erlebnisse, Erfahrungen und Erkenntnisse aus drei Jahrzehnten, ed. Matthias Voß (Münster: Lit, 2005), 278-313. 
sures $^{53}$ of the GDR impacted the everyday life of East Germans, especially when traveling or exploring the city. The photographs prove that East Germans always had to travel in groups, never alone. The existing tense political situation prohibited individual explorations. Therefore, East Germans not only photographed their workplaces, their homes or luxury goods-which they could purchase at the Intershop, a state-run retail store offering high-quality products made in GDR and western goods-but also the attacks or assaults on their workplaces. For example, there are numerous photographs of the Beira-Machipanda railway line, where the tracks and a bridge were constantly being destroyed. They also photographed gatherings and private parties with Mozambicans, contacts that they were not officially allowed to have. ${ }^{54}$

\section{The Photographer: The Moving Self}

While official state photographs provide a very clear and defined portrayal of development work by depicting projects on site and their impact on the Mozambican society, private photographs offer personal insights into the lives of East German specialists and their relationships with their Mozambican colleagues. In some of these photographs, the viewers are presented with group shots in which they can learn about the working environment and which encourage them to reflect on stories of collaboration and friendship.

Figure 1 shows a group shot of 14 Mozambican students with their East German teacher Rainer Grajek posing in front of the Centro de Formação dos Instrutores, the Trainee Center for Teachers in Maputo. Grajek was sent to train the students to become teachers in history and Marxism-Leninism..$^{55}$ After a successful completion of the course, the students were then sent out to the countryside to teach their own classes. It is noticeable to the observer that most of the students are men. The photograph also shows two younger children, a baby resting on the

53 Mitteilung der Abteilung Auslandsdienstreisen Nr. 02/1988, Schulungsmaterial zu den "Grundsätzen und Hinweisen für die Vorbereitung dienstlicher Reisen und für das Verhalten von dienstlich im Ausland weilenden Bürgern der DDR,” SAPMO-BArch, DC 20/11976.

54 Mitteilung der Abteilung Auslandsdienstreisen Nr 02/1988, SAPMO-BArch, DC 20/11976.

55 When Grajek first met the national director for the cadre training program in the Ministry of Education, the director explained to him that the country was in need of teachers. One of the requirements to train good teachers is the availability of qualified instructors. It was for this very reason that Grajek was sent to help train those cadres; Rainer Grajek, Berichte aus dem Morgengrauen: Als Entwicklungshelfer der DDR in Mosambik (Großbothen: Bücherwerkstadt \& Verlag Ute Vallentin, 2005), 64. For further details on Grajek's deployment in Mozambique see also Piepiorka and Buanaissa in this volume. 


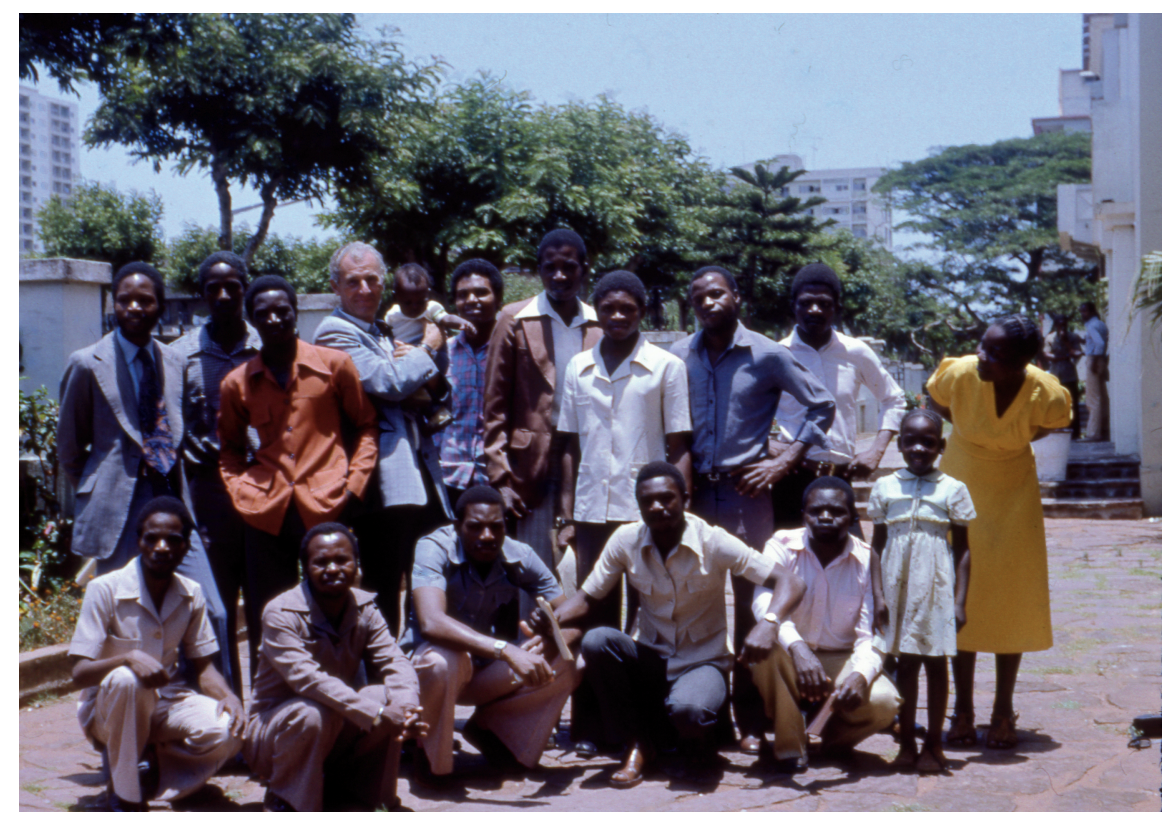

Figure 1: Rainer Grajek with his students in front of the Centro de Formação dos Instrutores (Training Center for Teachers) in Maputo. Source: Private Archive R.G.

arm of the East German instructor and a young girl standing in front of her mother. The woman is also the mother of the baby as can be inferred from the fact that she looks to the side to check on her child. She smiles comfortably as she looks at the East German holding her baby. In his memoir Berichte aus dem Morgengrauen, we learn about the special relationship between Grajek and that woman, Madalena Lhomulo. Growing up in the countryside, Lhomulo decided to attend missionary school in Lourenço Marques (today Maputo) where she finished the fourth grade in 1972. Due to racial discrimination, she only finished the introductory course in the secondary school she attended. She soon got married and gave birth to her first child. In 1976, she decided to go back to school while pregnant with her second child. After the birth of her third daughter in the 1980s, her husband decided to separate since she had not born him a son. While they were still living together, she gave birth to another child in 1982, this time a boy. However, the husband abandoned the family shortly after which left her alone to take care of their children. To make ends meet, she picked up evening courses and taught in several schools in Maputo. It was also in 1982 when she decided to join a training program to become an official teacher. During this time, she also gave birth to the baby featured in the photograph. Grajek and Lhomulo be- 
came very close during the time of the training. Both had children of the same age-a commonality that served as a starting point beyond the regular conversation of homework and work material. She started to take her newborn with her to classes, sometimes accompanied by her younger daughter who looked after her son while she was in class. Grajek and his wife visited Lhomulo several times at the boarding school where she stayed since she was not able to go back to her house in the Maputo suburbs due to war conflict. Grajek was impressed by her energy to juggle the many responsibilities she had to endure, which might have been the reason that he reached out to her. He was aware of her struggle and described it as such in his memoir: "It seemed like she was carrying an invisible weight on her slender, always bent, shoulders. [...] When she spoke one recognized optimism and confidence. When you looked into her eyes, you could also see fear." 56 Because women were expected to fulfill the traditional role of caretakers, it is not surprising to see so few women participating in such courses. Grajek wanted her to be successful because he saw her potential. The group pictures, however, allow us to reflect on another aspect of representation; they are never meant to be for the Mozambicans, but rather for the East Germans to draw attention to their students and apprentices. Those photographs not only validated their work abroad but also depicted the "other" again in the binaries of teacher and student, and therefore played an important role in the portrayal of the relationships between the subjects.

Occasionally, the East Germans also had portraits taken of themselves. For the majority of the East Germans, the impressions and experiences they captured in photographs contrasted with their lives in the GDR. Being aware that their work and travel abroad was a one-time opportunity from which most East Germans were excluded, the urge to document life abroad in all its details is understandable. With photographs, every important moment was captured as evidence and memory for later when they would have already returned home. Other photographs document the East Germans individually or with their families in their homes. While most of the East German specialists-who were deployed up to three years-were accompanied by their spouses with or without children, it also happened that the husband left for Mozambique first, followed by his family soon after. It was sometimes also the case that his wife and children had to stay behind during the time of his employment. In this situation, photographs added a visual element to the letters that were sent home. However, in the next photo-

56 "Sie schien eine unsichtbare Last auf ihren schmalen, stets etwas gebeugten Schultern zu tragen. [...]. Wenn sie sprach, erkannte man ihre Zuversicht. Wer in ihre Augen blickte, sah, dass in ihnen auch Angst wohnte.” Grajek, Berichte aus dem Morgengrauen, 76. 
graph, the East German who worked for the CFM (Caminhos de Ferro) in Beira, the Mozambican Ports and Railways authority, had to travel occasionally to various places in the hinterland to help with the installation of railroad tracks.

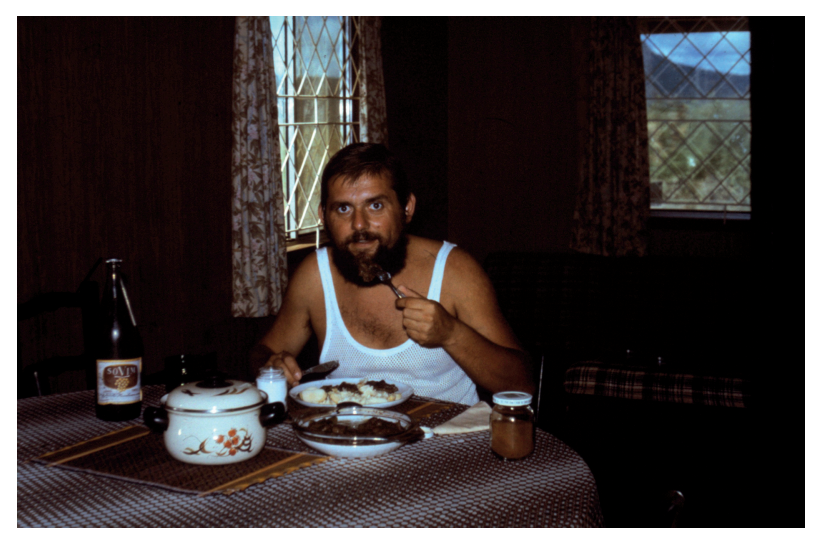

Figure 2: East German sitting at a table eating. Messica, 1983. Source: Private Archive T.B.

In Figure 2 we see the man sitting at the table and eating. The table is set for only one person. He is cautiously smiling into the camera, ready to dig into his food that was prepared for him by a Mozambican cook. The picture was taken in one of the houses in Ifloma, a woodwork factory in the small town of Messica in central Mozambique, which was turned into a guesthouse after the Swedish specialists-who had built those houses- unexpectedly left. It is a private moment, a portrait photograph, meant to serve as evidence that everything was going well abroad and that wife and family at home did not have to worry about their husband and father. Although those pictures mainly served a private purpose, they also show that the local supply in the northern and central region of Mozambique was more than sufficient with enough meat, fruits, and vegetables at hand. It was the coastal region neighboring Beira that did not receive supplies due to the destruction of the Moatize-Beira railroad and therefore failed to deliver the basic necessities. ${ }^{57}$ While the East Germans wanted to support as many projects

57 Jahresbericht 1980, Botschaft der DDR in der VRM, Maputo 5. Februar 1981, Politisches Archiv des Auswärtigen Amtes, Archiv des Ministeriums für Auswärtige Angelegenheiten der DDR, Berlin (henceforth PA AA), M 31 MfAA ZR 1658/83; Helmut Matthes, "Die Beziehungen der DDRVR Mosambik zwischen Erwartungen und Wirklichkeit: Ein Gespräch," in Wir haben Spuren hinterlassen! Die DDR in Mosambik: Erlebnisse, Erfahrungen und Erkenntnisse aus drei Jahrzehnten, ed. Matthias Voß (Münster: Lit, 2005), 12-33. 
as possible, the attacks of the resistant movement Resistência Nacional Moçambicana (RENAMO), and the small number of specialists working at institutions like the CFM, rendered them unable to sufficiently fulfill the needs for help and assistance. In fact, the coal production in Moatize started to decrease in 1982, and the installation of the textile factory in Mocuba, as well as the railroad corridor Beira-Moatize, were never fully completed. ${ }^{58}$

\section{Where Are the Women? Between Absence and Presence}

So far, studies of East Germans abroad have mainly been devoted to the labor of male specialists. ${ }^{59}$ Even though women worked as doctors, nurses, and teachers in Africa, their voices remain silent in the portrayal of mostly male specialists in official state photographs. ${ }^{60}$ This one-sided view of the male specialists in the workplace is challenged by private photographs. Although the photographers were primarily men, they made East German women in Mozambique visiblein their workplace, domestic environment, and with friends or at outings. One of the main privileges enjoyed by long-term East German specialists was the opportunity to bring their families with them. The prerequisite was that they met certain conditions, such as that they only brought children under or above a certain age, were loyal to the party and in good health. Women who accompanied their husbands on their work assignments were labeled as "accompanying spouses" (mitreisende Ehepartner). Although this term was theoretically for both men and women, it became apparent over the years that those co-travelling

58 Heide Künanz, "Das Steinkohleprojekt Moatize zwischen solidarischer Hilfeleistung und kommerziellem Anspruch," in Die DDR und Afrika: zwischen Klassenkampf und neuem Denken, ed. Ulrich van der Heyden, Ilona Schleicher, and Hans-Georg Schleicher (Münster: Lit, 1993), 174-191; Matthes, "Die Beziehungen der DDR zur Volksrepublik Mosambik in der Afrikapolitik der DDR,” 39-52.

59 Although material on women's work as specialists abroad is rare, the women's magazine Für Dich published on women working within the FDJ friendship brigades, for example a portrait of FDJ brigadier Margitta Bernstein who worked as a nurse in Angola, Für Dich 30/84, "Vom Glück helfen zu können," 27-29.

60 In her 2014 book Mocambique - Marcou-Nos Para A Vida. Grupo de Mulheres Internationalistas 1980-1984, Elisa Fuchs interviewed 15 women who worked in Mozambique as doctors, teachers, urban planners, lawyers, researchers, economists, and as professionals in ministries and public services. Not one of these women was from the former GDR. Fuchs is, however, so far, the only one writing about the deployment of women and their accomplishments in Mozambique. 
family members remained mostly women. The photographs show that the accompanying wives shaped how East German men understood their experience in Mozambique. Photographs outside the home were usually connected to the work environments of the husbands. In contrast, photographs inside the home were limited to women and their roles as housewives and mothers. These photographs typically focused on raising children, cooking, or meeting with other women. Photographs of women taking care of their children at home or during outdoor activities are a symbol of all-round childcare, a distraction for women during the day while their husbands were at work. It was a rare occasion that women also worked as specialists if there were children in the household. This housewife existence (Hausfrauendasein) contrasted sharply with the situation in the GDR, where the state expected women to work, and where children attended public kindergartens. ${ }^{61}$ The photographs also created an image of an GDR idyll abroad including typical East German activities, customs, and traditions, with children playing with an imported toy shop (Kaufmannsladen), the documentation of the first day at school with a sugar cone (Zuckertüte) in hand, or an Easter egg hunt (Ostereiersuche) in springtime. They show the clear assignment of gender roles within the marriage and seemingly fail to show the way in which women also contributed to the success or preservation of the projects in place. Instead, the viewer gets the impression of a protective and patronizing environment, which is reinforced by the man as photographer and decision-maker of the image motifs. The photographs show how men wanted to document women in this way, not how women experienced their lives in Mozambique.

Despite the male gaze of the private photographs that presented women in a domestic role, a few photographs showed East German women's activism in the premise of solidarity. Figure 3 is a collection from a photo album with various photographs stacked together on one page. A detailed look reveals that this collection did not depict one event but rather shots taken at various solidarity bazaars and events organized by these women. The solidarity events were celebrations in which so-called "solidarity packages" sent by the DFD, the Democratic Women's League of the GDR, were officially handed over to the OMM, the Organization of Mozambican Women in the presence of members of the national sec-

61 While it is difficult to get an exact number of how many men and women worked in Mozambique, archival material from the Federal Archive in Berlin such as Kaderakten and minutes of party meetings show a predominantly male presence. Most of the specialists in consulting positions were men while women filled the jobs of secretaries, teachers, doctors, and nurses. 
retariat of the OMM in Maputo and the FRELIMO party. ${ }^{62}$ Other events, such as those seen in Figure 3, were organized by East German women who had accompanied their husbands to Mozambique.

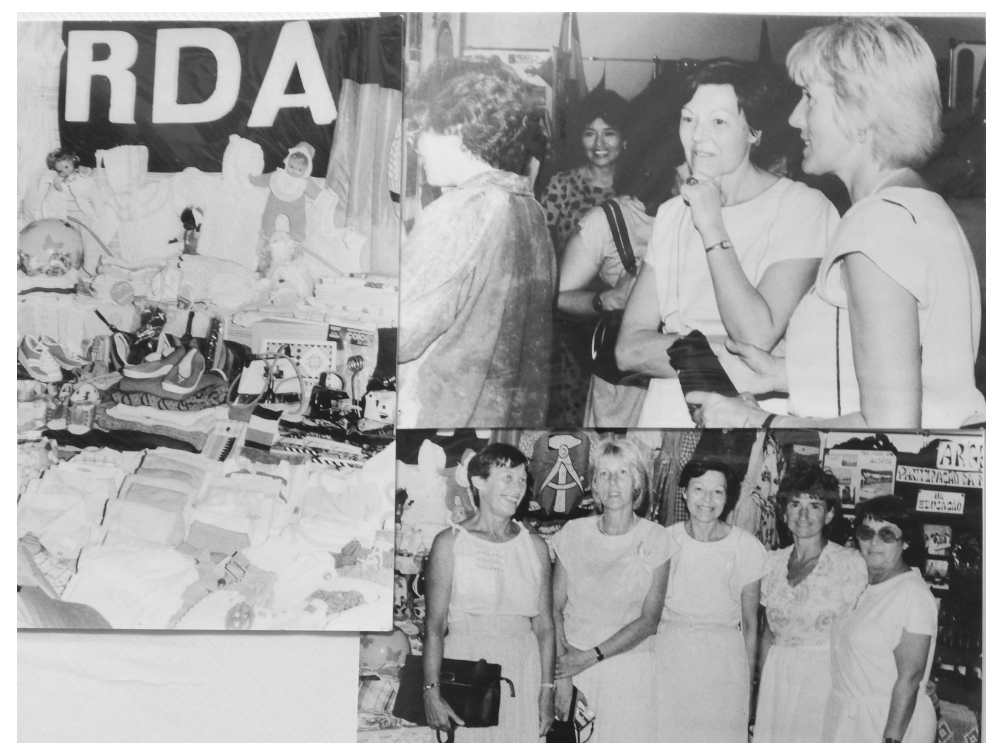

Figure 3: East German women organize a solidarity bazaar with other socialist countries in Maputo. Source: Private Archive K.L.

The above photograph depicts a group of East German women standing in front of the East German flag. They are participating in the annual solidarity bazaar at Maputo's main exhibition site. Every embassy had set up a booth to collect money. East German women sold clothing that they had brought back from the GDR while on vacation. ${ }^{63}$ The women stand in what seems to be their booth, proudly peering into the camera. Another photograph, which was used as a postcard, gives further information about what these women did: "This was your mom in action at the solidarity bazaar of socialist and sympathizing countries while decorating and setting up the booth. The other person here is the director of Intercoop, who coordinated the whole thing as the advertising expert. We were sweating which, fortunately, you can't see. But what you can see is your mother

62 Zusammenarbeit des DFD mit der Organisation der Mocambiquanischen Frau (OMM), Delegationsaustausch - Solidaritätssendungen, 1986-1988, SAPMO-BArch, DY 31/1461.

63 Interview with former accompanying wife L., conducted on April 27, 2016 in Petershagen. 
aging (unfortunately)." ${ }^{64}$ This postcard was sent to one of the women's children who had stayed at home. Instead of sending a letter that would describe the day of the solidarity bazaar, she decided to illustrate the event in form of a photograph as a documentation of her being "in action." Informing the children about their mothers' work abroad showed that the East German women in Mozambique understood themselves as part of the political project of promoting socialism and did not see themselves as mere domestic caregivers.

\section{Private Photographs and the "Other": Mozambique and Mozambicans}

As mentioned previously, official photographs taken by photo agencies played into the GDR's concept of solidarity and willingness to donate to legitimize its expatriates' work abroad. Representations of Africa and Africans in photographs and texts gave the GDR an opportunity to have their citizens reflect upon their own privileged living conditions, especially in times of crises, when East Germans would disapprove the state's policies or travel restrictions. The interplay of inferiority and superiority became particularly important through the representation of the "Other." ${ }^{65}$ Like the Soviet Union, the GDR struggled with its presence in Africa and the complex entanglements of race, exoticization, otherness, and stereotyping when the ideology-internationalism, solidarity, and humanist communism-clashed with realities on the ground. ${ }^{66}$

So, how do the private photographs fit into the concept of "othering"? And how were Mozambique and Mozambicans portrayed in the photographs? In his 2011 book Unter Moçambicanern: Arbeit - Leben - Abenteuer, 1979-1985, Udo Heiland, an East German specialist who worked for the planning commission in Maputo, describes one of his encounters with Mozambican women as follows: "As I started to take pictures of them, they got cranky and I stopped. There would

64 "Das war Eure Mutter in Aktion beim Solibasar der sozialistischen und sympathisierenden Länder beim Ausgestalten und Aufbau des Standes. Der andere Akteur ist der Leiter Intercoop, der als Werbefachmann natürlich den Hut aufhatte. Wie wir dabei geschwitzt haben, sieht man leider nicht, aber wie Eure Mutter eben auch älter wird (leider).” Postcard from L. to her children, date unknown, private archive. Author's own translation.

65 Stuart Hall, "Die zwei Paradigmen der Cultural Studies," in Widerspenstige Kulturen: Cultural Studies als Herausforderung, ed. Karl H. Hönring and Rainer Winter (Frankfurt/M.: Suhrkamp, 1999), 13-42.

66 Quinn Slobodian, “Introduction," in Comrades of Color: East Germany in the Cold War World, ed. Quinn Slobodian (New York: Berghahn Books, 2015), 3. 
be another opportunity later. Some black people at the beach seemed to be more open-minded. They sat in the water up to their belly and chuckled like children. (...) One of those beauties even spoke a few words of German.”77

As Heiland's observation shows, there was no need for a visual representation to imagine the described scene. Above all, this statement clearly illustrates how many East German men chose their photo subjects and how they captured them. In that context, the photographs support Susan Sontag's argument that the camera is a weapon that can "intrude, trespass, distort, and exploit." 68 The East Germans' photographs illustrate that taking pictures is more than just an innocent encounter. Instead, the encounter between the photographer -the GDR specialist on the one side and the Mozambican being photographed on the other-resembles a photographic assault, an invasion, in which the Mozambican women and men are at the photographer's mercy. The general interest of getting to know the "Other" has not remained merely in silent observation, on walks, shopping in the city, or writing about what those specialists experienced. Instead, everything is documented in photographs. They show what the feminist and film scholar Ann Kaplan meant in distinguishing between two concepts of observing someone or something: the "look" and the "gaze". While the former can be attributed to a process of seeing and observing in a way to understand one's own surroundings and relations to people, the latter receives special attention in a postcolonial discourse. The gaze here describes a "one-way subjective vision." ${ }^{69}$ As an active process, the gaze consumes the subject's own anxiety, whereby the object becomes a threat. ${ }^{70}$ In particular, traveling promotes an awareness of one's own national identity: "People's identities when they are traveling are often more self-consciously national than when they stay home. In addition, travel provokes conscious attention to gender and racial difference." ${ }^{71}$ In their travels and excursions to the countryside, East Germans participated in this kind of gaze.

67 "Als ich sie fotografieren wollte, hatten sie sich zickig, und ich ließ es sein. Es würde sich später noch Gelegenheit finden. Aufgeschlossener waren einige Schwarze am Strand. Sie saßen bis zum Bauch im Wasser und freuten sich wie Kinder, als wir ein Gespräch mit ihnen begannen. Eine der Schönen sprach sogar einige Brocken Deutsch.” Udo Heiland, Unter Moçambicanern: Arbeit - Leben - Abenteuer, 1979-1985 (Leipzig: Engelsdorfer Verlag, 2013), 40. Author's own translation.

68 Sontag, On Photography, 13.

69 Anne E. Kaplan, Looking for the Other: Feminism, Film, and the Imperial Gaze (New York: Routledge, 1997), xvi.

70 Kaplan, Looking for the Other, xviii.

71 Kaplan, Looking for the Other, 6. 
Most of the photographs reveal the surprise or discomfort of Mozambicans. They are photographed from close up or far away, and it seems that most of the shots were taken without asking for permission. In his 2013 travel memoir Als Auslandskader in Mosambik, the East German specialist Günter Mosler, who worked in the coalmine in Moatize during the 1980s, includes a series of photographs portraying his Mozambican colleagues. ${ }^{72}$ Those workers are seemingly placed in front of huts, be it in front of their own homes or local shops. All of them are depicted in the narrative of a "simple lifestyle". While Mosler refers to the house of one of his colleagues as Hütte (hut), another photograph showing Mosler's wife, their poodle Buffy, and his friends in front of their house which he captions as casa (house). We then observe how their privileged lifestyle is interrupted by begging children. To visually underpin the situation, Mosler introduces us to a 14-year-old boy named Boa Tard[e], Portuguese for "Good Afternoon". However, it is not only Boa Tard[e] begging for food, but he and his team, as Mosler captioned the picture he took of the group. The team refers to a situation that Mosler's wife experienced when she gave two begging children some bread, only to return later to a group of 20 children screaming and asking for food. This seemingly terrifying moment is then reinforced through the detailed description of Boa Tard[e] dressed in rags, smelling miserably with his feet and hands covered in wounds. ${ }^{73}$

Another method of taking authentic snapshots with the locals was to make use of one's own children. The natural urge of children to play with other children, who, in contrast to their parents, did not have to worry about a communication ban with the Mozambican population, served as a perfect basis for snapshots of everyday life. While some East Germans had no problems with their children playing with Mozambican children, there were some incidents in which women complained about the lack of hygiene of Mozambican children and their fear of diseases. ${ }^{74}$ However, the photographs that show East German children together with Mozambican children suggest that the separate housing arrangements of the East Germans in Mozambique did not impact the everyday relationships and contacts, at least when it came to children.

72 Günter Mosler, Als DDR-Auslandskader in Mosambik, 1979-1982: Zwischen Dschungel, Taiga, Savanne, Wüste und Heimat (Leipzig: Engelsdorfer Verlag, 2013), 48, 51, 53.

73 Mosler, Als DDR-Auslandskader in Mosambik (1979-1982), 61.

74 Interview with accompanying wife G. about her life in Mozambique, conducted on November 29, 2015 in Riesa. 


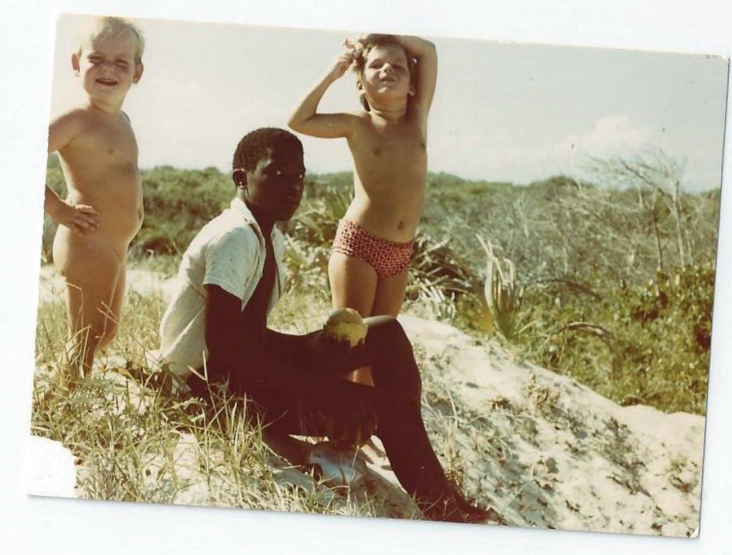

Figure 4: Two East German children with a Mozambican boy. Beira 1984. Source: Private archive T.B.

Often, the locals that were photographed were unknown to the photographer. ${ }^{75}$ Instead, they served as a general representation of the country and its people. In Figure 4, two East German children seem to be looking confidently into the camera; in contrast, the Mozambican adolescent looks into the camera reluctantly and his body language seems to be more defensive and insecure. This appearance of reluctance and discomfort can be seen in many other pictures as well. Although colonialism had in practice vanished, the memories and the various practices of how colonialism was implemented were still very present-especially in Mozambique. This trauma is described by Frantz Fanon as a constant state of anxiety in which the colonized looks for signs that place him in the racially divided world. ${ }^{76}$ In this vein, Mozambicans' encounters and interactions with white Europeans were still affected by the colonial past. While the GDR proudly looked upon its rhetoric of anti-colonialism and anti-racism, the East Germans' awareness of their place in the history of colonialism was largely ignored. For this very reason, the colonial gaze continued. ${ }^{77}$ Compared to the photographs depicting labor, in which East Germans pose with their colleagues and apprentices, the above photograph appears staged because there is no apparent relationship

75 My interview partners confirmed that photographs with Mozambican children taken at the beach or in the countryside were usually without any personal connection.

76 Bhabha, "Framing Fanon," ix.

77 Zeller and Weiss, Weisse Blicke, schwarze Körper, 7. 
between the people being photographed. With staging attempts that imitated an anchoring in local life, the East Germans tried to show that they had found entries and moorings in Mozambican society.

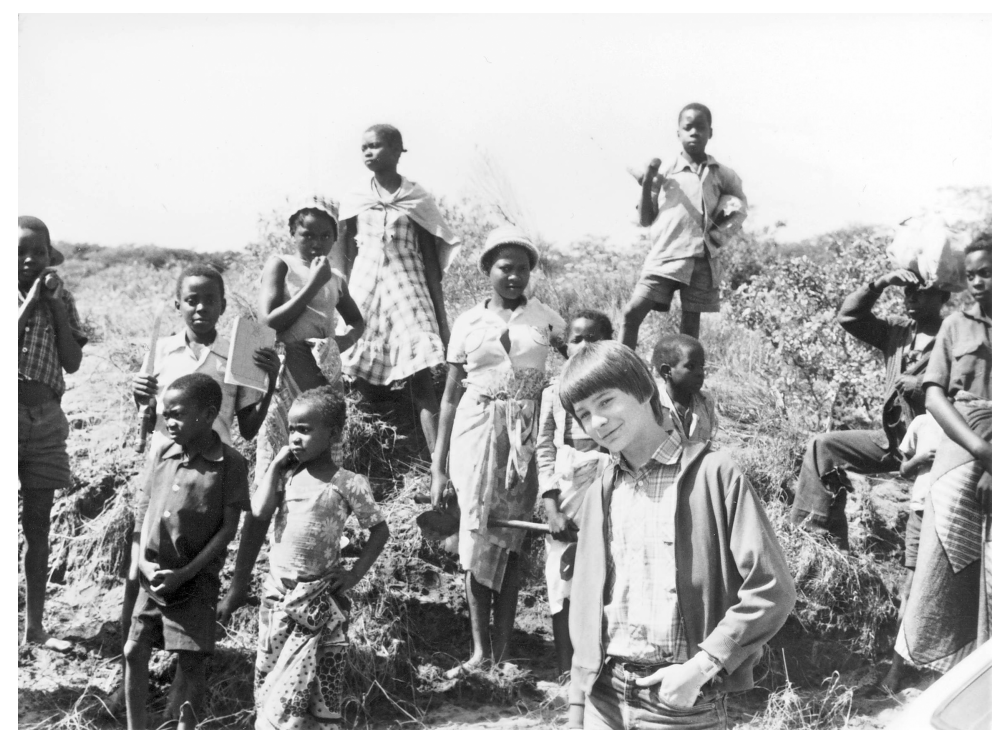

Figure 5: East German adolescent boy in front of a group of Mozambican children in Maputo. Source: Private Archive G.K.

The boy in Figure 5 had just arrived in Mozambique to visit his parents. This is one of the cases in which children were not allowed to accompany their parents because they were too old. The composition of this shot is a reminder of the established binaries of colonial representation. The boy is placed in the center of the frame with a group of young children and young adults in the background. It seems that children played at this spot-an opportunity that the East German photographer seized upon by placing his child in front. The photograph suggests that there is no relation between the photographer and the children in the background. Most of the children pay little attention to the photographic setup and seem to be more interested in something going on in the distance. The photograph looks like a collage of two photographs, which is due to the fact that the East German boy is so far away from the group of Mozambican children. Sontag describes such a situation as a duel moment, which "of- 
fers [...] both participation and alienation in our own lives and those of othersallowing us to participate, while confirming alienation. ${ }^{78}$

Compared to the young woman's confidence and the other children's indifference in the background of the picture, the East German boy seems to feel uncomfortable, posing with one hand in his pocket. His eyes are focused on the camera, behind which we can imagine the photographer asking him to smile. Although some of the children look intrigued with one young woman posing for the camera, the overall impression is that such encounters with white Europeans were not a rare incident but rather part of their everyday life. ${ }^{79}$ Under colonial rule, Mozambicans were consistently objectified due to their racial signifiers. The white gaze, an indicator for power, hegemony, and privilege, is what philosopher George Yancy calls a "historical achievement-a specific historical practice, socially collective and intersubjective, a process that is dutifully maintained." ${ }^{80}$ Within this white power, objectification of the black body was normalized. Especially in bigger cities such as Maputo or Beira, or in joint projects such as the coalmine in Moatize the number of international specialists was higher than in the more remote areas in the hinterlands. Assuming that other international specialists took similar photographs, the children were not only used to being photographed but also exposed to the camera's intrusion.

\section{Conclusion: The Use of Private Photographs in the Context of GDR Memory and Beyond}

Private photographs reveal what the official GDR rhetoric did not dare to say and what did not fit into the socialist image of the GDR. In fact, private photographs taken by East Germans in Mozambique represent more than just a technology for documenting life; like most technologies, they are themselves powerful agents. The socialist encounters of East Germans with Mozambicans show a different part of the everyday life in the East German society, namely that beyond the state apparatus and enactment. Today, these private photographs are important documents for researchers and even more important for the biographical stories

78 Sontag, On Photography, 167.

79 There are some studies that focus on body language and how the "look" can be identified as part of resistance. See Viktoria Schmidt-Linsenhoff, Ethnizität und Geschlecht: (Post-) Koloniale Verhandlungen in Geschichte, Kunst und Medien (Köln: Böhlau, 2005).

80 George Yancy, Black Bodies, White Gaze: The Continuing Significance of Race in America (Lanham: Rowman \& Littlefield, 2016), 243. 
of people whose lives have changed significantly since reunification. The visual portrayals of the work of East Germans abroad have yet to find access into the collective memory of the GDR. ${ }^{81}$ They show how East Germans saw themselves situated in the country among their Mozambican and international colleagues and apprentices, sometimes contrary to what the GDR had tried to implement. ${ }^{82}$ Furthermore, the framework of postcolonial theory I have used for analyzing some of the pictures reveals the enormous importance of photographs for investigating the East German relationships with Mozambique and Mozambicans then and now under the premise of Germany's colonial history.

Incorporating private photography into scholarly research challenges four underlying assumptions and opens further fields of research. Firstly, photographs facilitate the understanding of the work and life of East German citizens in the 1980s beyond the narrative of propaganda. This also includes different perspectives, such as that of East German women and their active engagement. Secondly, photographs place the perspectives of family, work, and travel in dialogue with different deployment locations and times that the East Germans spent in Mozambique. Furthermore, they help identify differences and similarities in studies of comparative systems such as those of the Federal Republic of Germany, the former Soviet Union, or other socialist and non-socialist countries that deployed their citizens on the African continent. Finally, an examination of photographs raises the question of how private pictures of East Germans fit into the representation of an "underdeveloped" Mozambique and how they contributed to-or challenged-that narrative. Private photographs can be interpreted as case studies into postcolonialism in their own right. Lastly, the private photographs serve as documentation of Mozambique's construction period as well as its wartime experiences during the 1980s. The photographs firmly place Mozambique within its own context of postcolonial history on the African continent.

81 The same can be said about the memory of Mozambican contract workers (Vertragsarbeiter) who returned to Mozambique after the unification of the two Germanys. For more information see Fernando Agostinho Machava's chapter in this volume, and Ibraimo Alberto and Marcia C. Schenck's chapter in this volume.

82 Including, for instance, travel restrictions, prohibited contacts to international, especially non-socialists colleagues, and individual explorations of a city or countryside. 


\section{Bibliography}

Baske, Siegfried, and Gottfried Zieger. Die Dritte Welt und die beiden Staaten in Deutschland. Asperg: Edition Meyn, 1983.

Bhabha, Homi. "Framing Fanon, Foreword." In The Wretched of the Earth, edited by Frantz Fanon, Richard Philcox, and Jean-Paul Sartre, vii-xli. New York: Grove Press, 2004 [1961].

Berman, Nina, Klaus Mühlhahn, and Patrice Nganang, eds. German Colonialism Revisited: African, Asian, and Oceanic Experiences. Ann Arbor: Michigan Press, 2018.

Büschel, Hubertus. Hilfe zur Selbsthilfe: Deutsche Entwicklungsarbeit in Afrika 1960-1975. Frankfurt am Main: Campus Verlag, 2014.

Büschel, Hubertus. "In Afrika helfen: Akteure westdeutscher "Entwicklungshilfe" und ostdeutscher "Solidarität" 1955-1975." In Dekolonisation: Prozesse und Verflechtungen 1945-1990, edited by Anja Kruke, 333-365. Bonn: Dietz, 2009.

Bartlett, Bruce R. “Capitalism in Africa: A Survey.” The Journal of Developing Areas 24 (1990): 327-350. www.jstor.org/stable/4191873.

Campt, Tina M. Image Matter: Archive, Photography, and the African Diaspora in Europe. Durham/London: Duke University Press, 2012.

Döring, Hans-Joachim, and Uta Rüchel. Freundschaftsbande und Beziehungskisten: Die Afrikapolitik der DDR und der BRD gegenüber Mosambik. Frankfurt am Main: Brandes und Apsel, 2005.

Edwards, Elizabeth. "Photography and the Material Performance of the Past." History and Theory 48 (2009): 130-150.

Edwards, Elizabeth, and Janice Hart, "Introduction: Photographs as Objects." In Photographs Objects Histories: On the Materiality of Images, edited by Elizabeth Edwards and Janice Hart, 1-15. London: Routledge, 2010.

Edwards, Elizabeth. "Objects of Affect: Photography beyond the Image." Annual Review of Anthropology 41 (2012): 221-234. doi:10.1146/annurev-anthro-092611-145708.

Fuchs, Elisa. Moçambique: Marcou-nos Para a Vida: Grupo De Mulheres Internacionalistas 1980-1984 Retratos E Depoimentos. Maputo: Ciedima, 2014.

Grajek, Rainer. Berichte aus dem Morgengrauen: Als Entwicklungshelfer der DDR in Mosambik. Großbothen: Bücherwerkstadt \& Verlag Ute Vallentin, 2005.

Hall, Stuart. "Die zwei Paradigmen der Cultural Studies." In Widerspenstige Kulturen. Cultural Studies als Herausforderung, edited by Karl H. Hönring and Rainer Winter, 13-42. Frankfurt/M.: Suhrkamp, 1999.

Hamelin, Candice. "Behind Immaterial and Material Divides: East German Photography 1949-1989." PhD diss., University of Michigan, 2016.

Harisch, Immanuel R., and Eric Burton. "Sozialistische Globalisierung: Tagebücher der DDR-Freundschaftsbrigaden in Afrika, Asien und Lateinamerika." Forthcoming in Zeithistorische Forschungen / Studies in Contemporary History.

Hartewig, Karin. "Einleitung." In Die DDR im Bild: Zum Gebrauch der Fotografie im anderen deutschen Staat, edited by Karin Hartewig and Alf Lüdtke, 7-12. Göttingen: Wallstein, 2004.

Heiland, Udo. Unter Moçambicanern: Arbeit - Leben - Abenteuer, 1979-1985. Leipzig: Engelsdorfer Verlag, 2013. 
Henniger, Gerhard. Zur gesellschaftlichen Wirksamkeit der Amateurfotografie in der DDR: Hinweise und Erfahrungen. Berlin: Dt. Kulturbund, 1965.

Isaacman, Allen F., and Barbara Isaacman. Mozambique: From Colonialism to Revolution. Boulder: Westview Press, 1985.

Jilek, Agneta Maria. “'Laßt uns pflügen, laßt uns bauen’: Brigadebilder und Typenporträts in der DDR-Fotografie der frühen fünfziger Jahre." In Die DDR im Blick II: Ein zeithistorisches Lesebuch, edited by Anja Hertel, Franziska Kuschel, and Markus Böick, 145-154. Berlin: Metropol, 2012.

Kaplan, Anne E. Looking for the Other: Feminism, Film, and the Imperial Gaze. New York: Routledge, 1997.

Künanz, Heide. "Das Steinkohleprojekt Moatize zwischen solidarischer Hilfeleistung und kommerziellem Anspruch." In Die DDR und Afrika: Zwischen Klassenkampf und neuem Denken, edited by Ulrich van der Heyden, Ilona Schleicher, and Hans-Georg Schleicher, 174-191. Münster: Lit, 1993.

Ludwig, Kurt. "Zwischen Anspruch und Anpassung: Der Kulturbund im kulturellen Alltag der DDR." In Die DDR zwischen Mauerbau und Mauerfall, edited by Heiner Timmermann, 126-138. Münster: Lit, 2003.

Lüdtke, Alf. Alltagsgeschichte: Zur Rekonstruktion historischer Erfahrungen und Lebensweisen. Frankfurt: Campus, 2018 [1989].

Matthes, Helmut. "Die Beziehungen der DDR-VR Mosambik zwischen Erwartungen und Wirklichkeit: Ein Gespräch.” In Wir haben Spuren hinterlassen! Die DDR in Mosambik: Erlebnisse, Erfahrungen und Erkenntnisse aus drei Jahrzehnten, edited by Matthias Voß, 12-33. Münster: Lit, 2005.

Mosler, Günter. Als DDR-Auslandskader in Mosambik, 1979-1982: Zwischen Dschungel, Taiga, Savanne, Wüste und Heimat. Leipzig: Engelsdorfer Verlag, 2013.

Niederhut, Jens. Die Reisekader: Auswahl und Disziplinierung einer privilegierten Minderheit in der DDR. Leipzig: Evangelische Verlagsanstalt, 2005.

Obernhummer, Iris Christina. "Experten der 'wissenschaftlich-technischen Zusammenarbeit' der DDR in Afrika: Alltag und Lebensweisen zwischen DDR- Richtlinien und angespannter Sicherheitslage in den 1970er und 1980er Jahren." Diploma thesis, University of Vienna, 2010.

Osterhammel, Jürgen. "'The Great Work of Uplifting Mankind”: Zivilisierungsmission und Moderne." In Zivilisierungsmissionen: Imperiale Weltverbesserung seit dem 18. Jahrhundert, edited by Boris Barth and Jürgen Osterhammel, 363-425. Konstanz: UVK, 2005.

Piepiorka, Alexandra. "Exploring "Socialist Solidarity" in Higher Education: East German Advisors in Post-Independence Mozambique (1975-1992)." In Education and Development in Colonial and Postcolonial Africa, Global Histories of Education: Policies, Paradigms, and Entanglements, 1890s-1980s, edited by Damiano Matasci et al., 289-318. Cham: Palgrave Macmillan, 2020.

Sandler, Willeke. "Deutsche Heimat in Afrika: Colonial Revisionism and the Construction of Germanness through Photography.” Journal of Women's History 25 (2013): 37-61. doi:10.1353/jowh.2013.0000.

Saul, John S. A Difficult Road: The Transition to Socialism in Mozambique. New York: Monthly Review Press, 1985. 
Schiermeyer, Regine. Greif Zur Kamera, Kumpel! Die Geschichte der Betriebsfotogruppen in der DDR. Berlin: Ch. Links, 2015.

Schleicher, Ilona, and Hans-Georg Schleicher. Die DDR im südlichen Afrika: Solidarität und Kalter Krieg. Hamburg: Institut für Afrikakunde, 1997.

Schleicher, Ilona. "Berufsbildung und Wirtschaftsbeziehungen der DDR-Mosambik." In Engagiert für Afrika: Die DDR und Afrika II, edited by Ulrich van der Heyden, Ilona Schleicher, and Hans-Georg Schleicher, 179-195. Münster: Lit, 1994.

Schleicher, Hans-Georg. "The German Democratic Republic (GDR) in the Liberation Struggle of Southern Africa." In Southern African liberation struggles: contemporaneous documents, 1960-1994, edited by A. J. Temu, and Joel das Neves Tembe, 507-598. Dar es Salaam: Mkuki na Nyota Publishers, 2014.

Schmidt-Linsenhoff, Viktoria. Ethnizität und Geschlecht: (Post-) Koloniale Verhandlungen in Geschichte, Kunst und Medien. Köln: Böhlau, 2005.

Slobodian, Quinn. "Introduction," In Comrades of Color: East Germany in the Cold War World, edited by Quinn Slobodian, 1-19. New York: Berghahn Books, 2015.

Slobodian, Quinn. "Socialist Chromatism: Race, Racism, and the Racial Rainbow in East Germany." In Comrades of Color: East Germany in the Cold War World, edited by Quinn Slobodian, 23-39. New York: Berghahn Books, 2015.

Smardz, Monika. "Bis zu jenem Tag im Dezember - Eine Farm mitten in der Savanne." In Wir haben Spuren hinterlassen! Die DDR in Mosambik: Erlebnisse, Erfahrungen und

Erkenntnisse aus drei Jahrzehnten, edited by Matthias Voß, 270-277. Münster: Lit, 2005.

Sontag, Susan. On Photography. New York: Picador, 1973.

Sontag, Susan. Regarding the Pain of Others. New York: Picador, 2003.

Stahr, Henrik. Fotojournalismus zwischen Exotismus und Rassismus: Darstellungen von Schwarzen und Indianern in Foto-Text-Artikeln deutscher Wochenillustrierter 1919-1939. Hamburg: Kovač, 2004.

Thompson, T. Jack. Light on Darkness? Missionary Photography of Africa in the Nineteenth and Early Twentieth Centuries. Grand Rapids: Eerdmans Publ., 2012.

van der Heyden, Ulrich. "Es darf nichts passieren! Entwicklungspolitisches Engagement der DDR in Mosambik zwischen Solidarität und Risiko." In Wir haben Spuren hinterlassen! Die DDR in Mosambik: Erlebnisse, Erfahrungen und Erkenntnisse aus drei Jahrzehnten, edited by Matthias Voß, 278-313. Münster: Lit, 2005.

Vokes, Richard, and Darren Newbury. "Editorial: Photography and African futures.” Visual Studies, 33, no. 1 (2018): 1-10. doi: 10.1080/1472586X.2018.1424988.

Voß, Matthias. "Um de nós - einer von uns! Gespräch mit Achim Kindler, der als Lehrer im Auftrag des Solidaritätskomitees der DDR als erster DDR-Bürger bei der FRELIMO arbeitete." In Wir haben Spuren hinterlassen! Die DDR in Mosambik: Erlebnisse, Erfahrungen und Erkenntnisse aus drei Jahrzehnten, edited by Matthias Voß, 34-46. Münster: Lit, 2005.

Voß, Matthias. Wir haben Spuren hinterlassen! Die DDR in Mosambik: Erlebnisse, Erfahrungen und Erkenntnisse aus drei Jahrzehnten. Münster: Lit, 2005.

Weis, Toni. "The Politics Machine: On the Concept of 'Solidarity' in East German Support for SWAPO." Journal of Southern African Studies 37 (2011): 351-367. doi:10.1080/03057070.2011.579443.

Winrow, Gareth M. The Foreign Policy of the GDR in Africa. Cambridge: Cambridge University Press, 1990. 
Witkowski, Gregory. "Between Fighter and Beggars." In Comrades of Color: East Germany in the Cold War World, edited by Quinn Slobodian, 73-94. New York: Berghahn Books, 2015.

Yancy, George. Black Bodies, White Gaze: The Continuing Significance of Race in America. Lanham: Rowman \& Littlefield, 2016.

Zeller, Joachim, and Peter Weiss, Weisse Blicke, schwarze Körper: Afrikaner im Spiegel westlicher Alltagskultur. Erfurt: Sutton Verlag, 2010.

Zuromski, Catherine. Snapshot Photography: The Lives of Images. Cambridge: The MIT Press, 2013.

\section{Magazines}

Horizont

Für Dich

Junge Generation

$N B I$

\section{Interviews}

Interview with former ADN journalist in Mozambique 1987-1990, conducted on June 15, 2016 in Berlin.

Interview with former specialist B. about the mailing of film material back to the GDR, conducted on June 2, 2016 in Berlin.

Interview with former accompanying wife L., conducted on April 27, 2016 in Petershagen.

Interview with accompanying wife G. about her life in Mozambique, conducted on November 29, 2015 in Riesa. 
